Kenneth Rochel de Camargo Jr.

\section{Public health and the knowledge industry}

\section{Saúde pública e indústria do conhecimento}

\begin{abstract}
Knowledge plays an important role in health care. The production and diffusion of health-related knowledge are increasingly under the control of private commercial interests, which are characterized by conflicts of interests that result in abuses of power. Considerable research has been done on the medicalindustrial complex and its role in the production of power imbalances and the consequent abuses, but little attention has been dedicated to the role played by the publishing industry, which can be subject to the same problems. The widely diffused idea that "frequent and major changes" occur in medicine, albeit unsupported by clearcut evidence, is an effective marketing tool for both the pharmaceutical and publishing industries, who feed and thrive on physicians' insecurities. The production and distribution of knowledge should be addressed as a strategic component of public health.
\end{abstract}

DESCRIPTORS: Knowledge. Scientific and Technical Publications. Publication Bias. Scientific Communication and Diffusion. Scientific Misconduct. Health Care Sector.

\section{RESUMO}

O conhecimento desempenha papel importante no cuidado em saúde. A produção e difusão do conhecimento em saúde estão atualmente cada vez mais sob controle de interesses comerciais privados, caracterizados por conflitos de interesses que resultam em abusos de poder. Embora esforços consideráveis tenham sido dedicados ao estudo do complexo médico-industrial e seu papel na produção de tais desequilíbrios de poder e abusos conseqüentes, pouca atenção tem sido dada ao papel desempenhado pela indústria de publicação, que pode estar sujeita aos mesmos problemas. A idéia amplamente difundida de que "mudanças importantes e freqüentes" ocorrem na medicina, ainda que sem claro apoio em evidências, é uma ferramenta de marketing efetiva das indústrias farmacêutica e de publicação, que se alimentam da insegurança dos médicos. A produção e distribuição do conhecimento deveriam ser abordadas como um componente estratégico da saúde pública.

DESCRITORES: Conhecimento. Publicações Científicas e Técnicas. Viés de Publicação. Comunicação e Divulgação Científica. Má Conduta Científica. Setor de Assistência à Saúde. 


\section{INTRODUCTION}

A recently published commentary ${ }^{22}$ strongly denounced how previous US government policies improperly undermined the findings of solid research in order to further a political agenda. The basic principle defended by the authors is clear: sound public policy requires sound science, and the latter is being artificially destabilized by political actions. That threatens the public's trust in public policies in general. In the authors' words, "The legitimacy, authority, credibility, and acceptability of our public policies depend on the public's trust in the validity of the processes that produced them." $22: 1939$

Unfortunately, the slogan "sound science" was hijacked by parties interested in anything but sound science, ${ }^{20}$ since it threatens their bottom line, as is demonstrated in the many papers that compose a 2005 supplement of the American Journal of Public Health. In its editorial, ${ }^{18}$ Michaels underlined the problems created, when judges evaluate the validity of scientific evidence, and how those problems are exploited by powerful litigants with inevitable repercussions in terms of public policy. The editorial made explicit reference to manufactured controversies around scientific knowledge (a gambit that became so widespread it earned the neologism, manufactroversy). An issue Another paper in the same supplement ${ }^{17}$ expanded on how that strategy was repeatedly used to trump proper regulatory policies intended to protect public health, with the tobacco industry being the most notorious case. The political maneuvering of the tobacco industry in order to compromise effective regulation is the subject of two other papers in the supplement. ${ }^{4,8}$

Many of the risks, to the integrity of the scientific enterprise and to the implementation of effective public health policy, are summarized in yet another paper in that supplement, ${ }^{30}$ suggestively titled "The Perils of Relying on Interested Parties to Evaluate Scientific Quality". Whereas the preceding authors describe a strategy of undermining good science for political or financial gain, I would like to point out that the same motivations could lead to hastily labeling problematic knowledge as established science. In a sense, most of the assessment of scientific quality in health is being delegated to financially interested parties. The thesis I am trying to establish is that the ever growing commercialization (and commodification) of knowledge inherently poses increased health risks for the general population. Biomedical knowledge was singled out for this exercise given its core role in public health; medical care is a key component to public health in many ways, including in terms of total health expenditure.

Health interventions, be they at an individual level through a physician interacting with a patient or at a community level through public health policies, depend on trusted bodies of knowledge. Those bodies of knowledge may not determine the interventions ${ }^{6}$ but at the very least they play a key role in the decisionmaking process that leads to concrete actions and play a key role in justifying decisions in the public arena, when necessary. The trusted status of such bodies of knowledge is the result of an unstable equilibrium; new knowledge, quite often at odds with previously accepted truths, is constantly generated by ongoing research. This is a complex process, which demands resources and dedication, with a group of experts - scientists - being in charge. The expert scientists produce knowledge and assure its quality, while average physicians are users of this knowledge, and the physicians rely in varying degrees on the expertise of scientists for the reliability of the statements. This does not mean that doctors have it easy keeping up with the moving target of knowledge and with the demanding and time-consuming activities of the profession. The changing knowledge base creates yet another reason why they have to rely on secondhand, when it comes to knowledge validity claims. ${ }^{6}$ Yet, accurate, up-to-date knowledge, is a major asset to them, not only for informing their actions but also for maintaining their professional identity; in the end, what separates proper doctors from quacks is precisely the ownership and mastery of their specific body of knowledge.

This puts physicians in a bind: they depend on a product - knowledge - the production and quality of which they do not control.

\section{MANUFACTURING BIOMEDICAL KNOWLEDGE}

The establishment of a fact in medicine depends upon human power and material resources on a scale that only a handful of major players can fund. The pharmaceutical companies are key players and have a clear interest in doctors prescribing their new drugs at some point.

This creates a major potential for problems - euphemistically called "conflicts of interest" - which have been the subject of intense debates over the last two decades. ${ }^{15,19}$ Regardless of the ongoing debate and attempts by numerous editors to reign in conflicts of interest, the current state of affairs is still far from satisfactory, as Chalmers, the past director of the Cochrane Centre, recently noted. ${ }^{7}$

Symptomatically, a slew of books was recently published within months of each other, ${ }^{1-3,13}$ addressing (or, more precisely, decrying) the innumerable problems that arise from the dominance of commercial interests in the production of medical knowledge. As one of those authors accurately states, "the role of 
the drug and medical-device companies has evolved so that their most important product is 'scientific evidence.' This is what drives sales." $1: 94$

Each one of those authors analyzes and exposes different aspects of the array of institutions, agents and interests that gravitate around health care, a conglomerate aptly labeled the medical-industrial complex. Problems, distortions and outright ethical (if not criminal) violations take place in the development of new drugs, new technologies, their approval and dissemination. Among their examples are strategies that include purposefully distorting experimental data in order to obtain a favorable result; propping up of key medical figures as endorsers of new drugs; the production of papers by ghost writers, which are simply signed by presumably respectable researchers; the various gifts provided to doctors (Reidy ${ }^{20}$ provides a detailed account of those strategies from the point of view of a pharmaceutical sales rep); lobbying to weaken or bypass government regulation; control of the content of continued medical programs and so on and so forth.

What is important to stress is that those problems are more or less unavoidable given the current state of affairs. There is a power struggle over the validity of certain statements, and as long as one of the contenders is the proverbial eight hundred pound gorilla and no effective checks-and-balances are in place, the outcome is predictable. No matter how skeptical doctors may be of claims from the industrial side of the medicalindustrial complex, given the disproportionate amount of resources available to the latter, in the end, doctors have no choice but to submit. ${ }^{5: 849}$ This point is also made in different ways by the mentioned authors. Abramson states that "although many doctors have a gut feeling that there is a pro-industry bias in the scientific evidence that guides their care, almost all the information that comes their way, including the opinions of the experts they trust, reinforces the validity of this 'knowledge", 1:97 Besides, Avorn ${ }^{3}$ wrote that "as long as the nation continues to allow most clinical research on drugs to be conducted by and for the companies that manufacture these products, who stand to gain or lose literally billions of dollars over their results, we are not going to get all the answers we need to our questions about drug efficacy and safety... or feel secure that the right questions are even being asked". 3:xii-xiv The issue is not so much research funding - a favorite argument of the pharmaceutical industry in justifying high drug prices and patents- but the control of the results. For Goozner $^{10}$ and Angell ${ }^{2}$ a much higher proportion of medical research funding comes from government or other non-profit sources than generally thought. Nevertheless, commercial interests (including those of universities, who were allowed from the eighties onwards to patent drugs even when they received government funding for the basic research behind the patent claim) manage to control the production of knowledge and present to the public an exaggerated version of their role in its development.

\section{SELLING KNOWLEDGE}

Knowledge is an abstract product, but it depends on some kind of material support in order to effectively circulate. Committing knowledge to paper creates a knowledge product, and once the printing takes place, we have a material product mirroring the abstract one.

The justified concern with the abstract part of the process has left the material expressions of knowledge practically unexamined. Far from being a neutral battleground, specialized journals and books have a very active role in the establishment of what counts as "scientific evidence" and a commercial dimension of their own, which often add to the more easily perceived issues dealt with in the previous section.

Although there are many journals and books, the relevant publishers are relatively few, and their total number has been decreasing over time as a result of mergers that have occurred in the publishing industry over the last decades. This has created some concern about the effects of concentration on the circulation of ideas and its associated costs. ${ }^{27}$ Another reason for concern is the embarrassing connections of such publishing conglomerates with other types of businesses. As a recent paper from the British Medical Journal states, "in a recent editorial in the Journal of the Royal Society of Medicine, Richard Smith drew attention once again to the paradoxical and disturbing association between Reed Elsevier, a huge global publishing company, and the international arms trade" ${ }^{31: 547}$ Although relentless pressure from the global scientific community eventually led Elsevier's parent company to withdraw from that line of business, it is still an embarrassment that it took so long.

In concentrated and specialized markets, competition is not price-based but relies on product differentiation. An example concerning the medical publishing industry can be derived from an analysis of the U.S. Periodical Price Index 2005. ${ }^{\text {a }}$ The price of subscriptions to medical journals is ranked third highest on average and had the highest average increase over ten years. Medical books are notoriously expensive, even when compared with similar publications.

Proof of the importance placed on product differentiation is the value attached to artificial measurements of a journal's importance, particularly on the impact

a Dingley B. U. S. Periodical Prices -2005. Chicago: American Library Association; 2005[cited 2007 Mar 20]. Available from: http://www.ala. org/ala/alctscontent/alctspubsbucket/alctsresources/general/periodicalsindex/05USPPI.pdf 
factor. Although even its creator, Garfield, clearly criticized its use in evaluation exercises, ${ }^{9}$ and criticism has mounted over its usage being extended beyond reasonable use. ${ }^{24}$

Attempts to restrict the adoption of new technologies that might threaten the dominance of the current major players are another important consequence of this type of market. In the case of publishing, this is represented by the dazzling new possibilities presented by the internet as a means to disseminate information. The reaction one of the most important medical journals, The New England Journal of Medicine (NEJM), to the new technology is quite telling. In an editorial originally published in 1995, the then editor of the NEJM obliquely stated that sending a paper through e-mail to more than two dozen people would configure prior publication and thus void it from submission to the NEJM. ${ }^{12}$ This policy is still in place Contrast that with the practises of the physics community, where general availability of preprints is the norm, and papers are published only after being available online for a while and thus strengthened by vigorous debate. This difference is addressed in Kassirer's editorial, who attributes the more stringent policies of medical journals to the need to protect the general population from widespread adoption of poorly grounded knowledge that could threaten their health. Considering the numerous and recurring problems created by papers that nevertheless passed the gatekeeping processes of journal publishing, one has to wonder if that argument has any merit.

Taking the preceding discussion into account, it should be clear by now that the medical publishing industry is an integral part of the medical-industrial complex, and thus affected by the same conflicts and problems that have been extensively documented with regards to its more visible pharmaceutical and medical equipment counterparts.

\section{WHEN RESEARCH AND MARKETING STRATEGIES CONVERGE}

An influential manual on evidence-based medicine states in its initial pages that "new types of evidence are now being generated which, when we know and understand them, create frequent, major changes in the way that we care for our patients". 23:5 This idea is repeated over and over by different sources, and the evidence presented for it is usually the gargantuan volume of papers printed every year by medical journals, already unmanageable as it is and increasing geometrically in numbers. But does this confirm the existence of "frequent, major changes" in medical knowledge?
Let us consider one specific segment of that knowledge, drug usage. The pharmaceutical industry would vigorously endorse the assumption of a quickly changing medical landscape; a pamphlet, downloadable from their website, ${ }^{\mathrm{a}}$ opens with the following sentence: "Over the past decade, pharmaceutical companies have pushed the scientific envelope, working at the cellular and molecular levels to dramatically advance the treatment of disease. At the end of 2002, 28\% more medicines were being investigated by pharmaceutical companies for approval by the Food and Drug Administration (FDA) than was true one decade before. More than 1,000 medicines are now in the development pipeline." However, as both Goozner ${ }^{10}$ and Angell ${ }^{2}$ point out, the majority of those drugs are the so-called "me-too" drugs. These substances do not represent major pharmaceutical innovations but small modifications of already existing products, in order to join the bandwagon of a commercially successful chemical or to get extended patent protection. ${ }^{2,10}$ A 2002 study by the National Institute for Health Care Management stated that "highly innovative drugs - medicines that contain new active ingredients and also provide significant clinical improvement - are rare. Over the 12-year period examined, just 153 out of a total of 1,035 new drug approvals (or $15 \%$ ) were for such drugs, priorityrated NMEs [New Molecular Entity]. Lipitor, Viagra, Fosamax, Avandia, Actos, and Plavix were among the drugs in this category. By contrast, drugs providing modest innovation are common. In 1989-2000, 472 new drugs or $46 \%$ of the total approved were standard IMDs [Incrementally Modified Drug]". ${ }^{28: 3}$

Some disheartening signs have also emerged concerning the content of what is published. In an editorial on PLoS/ Medicine (incidentally, an open-access journal), Smith, previously editor of the British Medical Journal for 25 years, vigorously denounced the publishing of clinical trials as nothing but a marketing tool for the pharmaceutical industry. ${ }^{25}$ Not long after that, the same journal published a dozen articles on disease mongering, that is, the industry-sponsored "discovery" of new diseases (or the extension of already known ones) that coincidently could help the sales of specific drugs. Papers on erectile dysfunction, ${ }^{16}$ female sexual dysfunction ${ }^{29}$ and bipolar disorder ${ }^{11}$ are among the most remarkable.

Steinman et al were able to detail the multi-pronged marketing strategy of the pharmaceutical industry through a case study on gabapentin based on internal documents obtained through litigation. ${ }^{26}$ In their conclusion, they write that "research, publications, and educational programs (including 'independent' events) were used as marketing opportunities, augmented by opinion leaders and local physician champions to engage their physician colleagues" ${ }^{26: 290}$

a The Pharmaceutical Research and Manufacturers of America. A decade of innovation: advances in the pharmaceutical treatment of disease. Washington; 2003 [cited 2007 abr 16]. Available from: http://www.phrma.org/files/Decade_of_Innovation.pdf 
These actions are complemented through vigorous advertising of prescription drugs to the general public through the poorly disguised formula of "ask your doctor about...", a strategy that has already been demonstrated as having the industry's desired effects on prescription patterns. ${ }^{14}$

It seems, then, that while it is safe to assume that there are indeed frequent or major changes in medical knowledge, the major changes are not frequent and vice-versa. The only supporting evidence of that claim is the sheer volume of medical publications, but this volume says nothing for the quality, timeliness or necessity of the content being published and can more easily be attributed to the drive of "publish or perish" policies than anything else. The academic job market and the evaluation of research grants has been increasingly reliant on bibliometric evaluations. The goal is not just publishing anywhere, but in the high impact factor journals or in books by the most prestigious publishers, which in turn are controlled by a small number of companies and so on and so forth. Again, market logic creates its self-vindication.

The "frequent, major change" myth and the epic output of the publishing industry, however, have a very definite effect with important economic implications: they feed and thrive on doctors' insecurity. Doctors feel constantly threatened that they and their knowledge will become obsolete at any moment and that only exhaustive efforts will help them keep abreast in this sea of change; yet they will never completely succeed.

This creates a pliable market for both the pharmaceutical and publishing industries. Insecure practitioners will willingly pay the rising prices of already expensive journal subscriptions (or books that have a limited shelf life, or subscribe to equally expensive online services) in order to allay their fear of obsolescence. Quite likely they will not have the time and/or resources to read through the mounting piles of papers, but will only perfunctorily scan some of those, selectively looking at abstracts and often literally jumping to conclusions. This reinforces their reverence for the epistemic authority of the people, who wrote those papers, and makes them more susceptible to the claims and strategies of the pharmaceutical representatives swarming around medical offices or to continuing medical education programs that are little more than a front for the same industry. Commercial interests- that have demonstrated over and over again that they cannot be trusted to self-regulate - are in control of the full cycle of production and distribution of medical knowledge, with dire consequences in terms of costs and quality of health care.

\section{CONCLUSIONS}

The old adage, knowledge is power, still holds true. To it I would add a corollary: those who control knowledge are the most powerful of all.

It should be clear by now that knowledge is as much an essential to public health as vaccines or screening tests are, and should thus be treated accordingly. The production and circulation of medical knowledge should be unburdened from commercial interests that do not necessarily align with the interests of health care professionals or the general population. When those sets of interests conflict, the outcome in the current climate is easily predictable.

\section{REFERENCES}

1. Abramson J. Overdo\$ed America: the broken promise of American medicine. New York: Harper Perennial; 2005.

2. Angell M. The truth about the drug companies: how they deceive us and what to do about it. New York: Random House; 2005.

3. Avorn J. Powerful medicines: the benefits, risks and costs of prescription drugs. New York: Vintage Books; 2005.

4. Baba A, Cook DM, McGarity TO, Bero LA. Legislating 'sound science': the role of the tobacco industry. Am J Public Health. 2005;95(Supl 1):20-7. DOI:10.2105/ AJPH.2004.050963

5. Camargo Jr KR. The thought style of physicians: strategies for keeping up with medical knowledge. Soc Stud Sci. 2002;32(6):827-55. DOI:10.1177/030631270203200501

6. Camargo Jr K, Coeli CM. Theory in practice: why "good medicine" and "scientific medicine" are not necessarily

the same thing. Adv Health Sci Educ Theory Pract. 2006;11(1):77-89. DOI:10.1007/s10459-005-6924-7

7. Chalmers I. From optimism to disillusion about commitment to transparency in the medicoindustrial complex. J R Soc Med. 2006;99(7):337-41. DOI:10.1258/jrsm.99.7.337

8. Friedman LC, Daynard RA, Banthin CN. How tobaccofriendly science escapes scrutiny in the courtroom. Am J Public Health. 2005;95(Supl 1):16-20. DOI:10.2105/ AJPH.2004.046227

9. Garfield E. How can impact factors be improved? BMJ. 1996;313(7054):411-3.

10. Goozner M. The $\$ 800$ Million dollar pill: the truth behind the cost of new drugs. Berkeley: University of California Press; 2004.

11. Healy D. The latest mania: selling bipolar disorder. PLoS Med. 2006;3(4):185. DOI:10.1371/journal. pmed.0030185 
12. Kassirer J. The internet and the journal. N Engl / Med. 1995[cited 2007 Mar 27];332(25): 27-30. Available from: http://www.nejm.org/general/text/policies.pdf

13. Kassirer J, On the Take: How medicine's complicity with big business can endanger your health. Oxford: Oxford University Press; 2005.

14. Kravitz RL, Epstein RM, Feldman MD, Franz CE, Azari $\mathrm{R}$, Wilkes MS, et al. Influence of patient's requests for direct-to-consumer advertised antidepressants. JAMA. 2005;293(16):1995-2002. DOI:10.1001/ jama.293.16.1995

15. Lexchin J, Bero LA, Djulbegovic B, Clark O. Pharmaceutical industry sponsorship and research outcome and quality: systematic review. BMJ. 2003;326(7400):1167-70. DOI:10.1136/ bmj.326.7400.1167

16. Lexchin J. Bigger and Better: How Pfizer Redefined erectile dysfunction. PLoS Med. 2006;3(4):132. DOI:10.1371/journal.pmed.0030132

17. Michaels D, Monforton C. Manufacturing uncertainty: contested science and the protection of the public's health and environment. Am J Public Health. 2005;95 (Supl 1):39-48. DOI:10.2105/AJPH.2004.043059

18. Michaels D. Scientific evidence and public policy. Am J Public Health. 2005;95 (Supl 1):5-6. DOI:10.2105/ AJPH.2005.065599

19. Neale AV, Schwartz KL, Bowman MA. Conflict of interest: can we minimize its influence in the biomedical literature? I Am Board Fam Med. 2005;18(5):411-3. DOI:10.3122/jabfm.18.5.411

20. Neff RA, Goldman LR. Regulatory parallels to Daubert: stakeholder influence, 'sound science', and the delayed adoption of health-protective standards. Am J Public Health. 2005;95(Supl 1):81-91. DOI:10.2105/ AJPH.2004.044818

21. Reidy J. Hard Sell: the Evolution of a Viagra Salesman. Kansas City: Andrews McMeel Publishing; 2005.
22. Rest KM, Halpern MH. Politics and the erosion of federal scientific capacity: restoring scientific integrity to public health science. Am J Public Health. 2007;97 (11):1939-44. DOI:10.2105/AJPH.2007.118455

23. Sackett DL, Straus SE, Richardson WS, Rosenberg W, Haynes RB. Evidence-Based Medicine: How to Practice \& Teach EBM. Edinburgh: Churchill Livingstone; 1997.

24. Smith R. Unscientific Practice Flourishes in Science. BMJ. 1998;316(7137):1036.

25. Smith R. Medical journals are an extension of the marketing arm of pharmaceutical companies. PLoS Med. 2005;2(5):138. DOI:10.1371/journal. pmed.0020138

26. Steinman MA, Bero LA, Chren MM, Landefeld CS. Narrative review: the promotion of gabapentin: an analysis of internal industry documents. Ann Intern Med. 2006;145(4):284-93.

27. Tamber PS. Is scholarly publishing becoming a monopoly? BMC News Views. 2000;(1):1.

28. The National Institute for Health Care Management Research and Educational Foundation. Changing patterns of pharmaceutical innovation. Washington; 2002.

29. Tiefer L. Female sexual dysfunction: a case study of disease mongering and activist resistance. PLoS Med. 2006;3(4):178. DOI:10.1371/journal.pmed.0030178

30. Wagner $\mathbf{W}$. The perils of relying on interested parties to evaluate scientific quality. Am J Public Health. 2005;95(Supl 1):99-106. DOI:10.2105/ AJPH.2004.044792

31. Young C, Godlee F. Reed Elsevier's arms trade. BMJ. 2007;334(7593):547-8 DOI:10.1136/ bmj.39153.580023.80 